\title{
GENTAMICIN AND METHICILLIN RESISTANT STAPHYLOCOCCUS AUREUS IN DUBLIN HOSPITALS: MOLECULAR STUDIES
}

\author{
G. Dowd, Mary Cafferkey and G. Dougan \\ Department of Microbiology, Moyne Institute, Trinity College, \\ Dublin 2, Ireland
}

\begin{abstract}
SUMmaRY. A large number of Staphylococcus aureus strains resistant to gentamicin, methicillin and other antibiotics, isolated in several Dublin hospitals during a 4-year period, were screened for plasmid DNA. Isolates assigned to four principal phage groups showed uniform plasmid profiles. A plasmid of mol. wt $21.0 \times 10^{6}$ encoding penicillin resistance was present in all isolates screened. A tetracycline resistance plasmid of mol. wt $24.0 \times 10^{6}$ was present in $40 \%$ of isolates of phage types 90 and 5/47/54/84/85 whereas a plasmid of mol. wt $3.0 \times 10^{6}$ was responsible for tetracycline resistance in isolates of phage types 77 and 85. Aminoglycoside, methicillin and erythromycin resistances were apparently not encoded on plasmids. Gentamicin resistance was transduced at low frequency between several strains of $S$. aureus and the resistance phenotype was due, in part at least, to the production of an inactivating enzyme.
\end{abstract}

\section{INTRODUCTION}

Several recent reports have described the isolation of Staphylococcus aureus strains resistant to gentamicin, methicillin and other antibiotics. (Shanson, Kensit and Duke, 1976; Price, Brain and Dickson, 1980; Hone et al., 1981). As with other bacteria, antibiotic resistance can be either chromosomally or plasmid encoded in $S$. aureus (Lacey, 1975; Shanson, 1981). However, unlike many plasmids found in gram-negative organisms, those in $S$. aureus do not appear to promote conjugative transfer of genetic material between strains. Transfer of antibiotic resistance determinants between $S$. aureus strains has been achieved in the laboratory using bacteriophages as vectors and similar transfer events could be responsible for the spread of antibiotic resistance between strains in the hospital environment (Novick et al., 1979; Lacey and Lord, 1980).

At present it is not fully understood how antibiotic resistance determinants become established within $S$. aureus strains present in hospitals. Although genetic studies have been performed on antibiotic resistance genes in $S$. aureus, few attempts have been made to conduct a large survey by plasmid screening and simple genetic techniques to identify the mechanisms of antibiotic resistance present in large numbers 
of related hospital isolates. Such a survey could be useful for collecting epidemiological information on the spread of multiple antibiotic resistance amongst $S$. aureus strains in hospitals.

Since 1976, gentamicin and methicillin resistant $S$. aureus (GMRSA) have been a major cause of infections in Dublin hospitals. Clinical studies have been conducted on these strains (Cafferkey et al., 1983) which were shown to belong to a limited number of phage groups (Williams and Rippon, 1952). In parallel with clinical studies we have used simple molecular and genetic approaches to identify the genetic basis of antibiotic resistance in these strains and the results of the study are presented in this report.

\section{MATERIALS AND METHODS}

S. aureus strains, antibiotic susceptibility testing and phage typing. All clinical isolates of $S$. aureus used in this study were isolated in the Federated Dublin Voluntary Hospitals (F.D.V.H.) or the Mater Misericordiae Hospital (M.M.H.), Dublin. The sources of the strains, antibiotic susceptibility testing and phage typing methods are described in detail in an accompanying paper (Cafferkey et al., 1983). Strains for plasmid screening were stored in $40 \%(\mathrm{w} / \mathrm{w})$ glycerol at $-20^{\circ} \mathrm{C}$. Recipient strain RN2677 and strains RN3612 and RN3499 that contained reference marker plasmids were obtained from Dr R. Novick (New York, USA). Strain RN3499 contained plasmids pI524 (mol. wt $\left.21.4 \times 10^{6}\right)$, pT181 $\left(3.0 \times 10^{6}\right)$, pE194 $\left(2.4 \times 10^{6}\right)$ and pC194 $\left(1.8 \times 10^{6}\right)$; strain RN361 contained a plasmid of mol. wt $5.3 \times 10^{6}$. Recipient strain SA1030 was described by Lacey and Lord (1980). Organisms were routinely cultured on Nutrient Agar or in Nutrient Broth (Oxoid).

Rapid screening of isolates for plasmid DNA. Isolates were screened by a modification of the technique of Hansen and Olsen (1978). Cells were harvested from $2 \mathrm{ml}$ of an overnight nutrient broth culture using an Eppendorff Microfuge (model 5412). The pellet was washed once in 500 $\mu \mathrm{l}$ of $50 \mathrm{~mm}$ trishydroxylmethylaminomethane (Tris- $\mathrm{HCl}$ ), $10 \mathrm{~mm}$ ethylenediaminetetra-acetic acid (EDTA) at $p \mathrm{H} \mathrm{8.0} \mathrm{(TE} \mathrm{buffer)} \mathrm{and} \mathrm{resuspended} \mathrm{in} 40 \mu \mathrm{l}$ of TE buffer; $10 \mu \mathrm{l}$ of lysotaphin (Sigma) $1 \mathrm{mg} / \mathrm{ml}$ in $50 \mathrm{~mm}$ Tris- $\mathrm{HCl}, p \mathrm{H} 7.5$, was then added. After incubation at $37^{\circ} \mathrm{C}$ for 10 min, $600 \mu \mathrm{l}$ of freshly prepared lysing buffer (TE buffer containing $4 \% \mathrm{w} / \mathrm{v}$ sodium dodecyl sulphate (SDS), $p \mathrm{H} 12.35$ ) was added and incubation was continued for a further 20 min to lyse

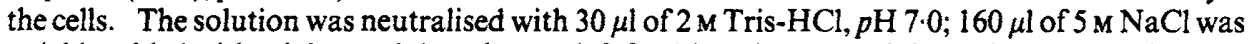
quickly added with mixing and the tube was left for $1 \mathrm{~h}$ on ice to precipitate chromosomal DNA. This appeared as a white floccular material and was removed by centrifugation for $15 \mathrm{~min}$ in the Microfuge. The supernate was decanted into a second microtube containing $550 \mu \mathrm{l}$ of isoproponol; the tube was held at $-20^{\circ} \mathrm{C}$ for at least $30 \mathrm{~min}$ then centrifuged for $5 \mathrm{~min}$ in the Microfuge. The supernate was discarded and the open tube was dried under vacuum. The dried precipitate was resuspended in $40 \mu \mathrm{l}$ of TE buffer and either run in $20 \mu \mathrm{l}$ portions through an agarose gel or stored at $-20^{\circ} \mathrm{C}$ until required. Samples were electrophoresed in $0.7 \%(\mathrm{w} / \mathrm{v})$ agarose gels at $70 \mathrm{~V}$ according to the method of Meyers et al. (1976). Up to 16 isolates could be screened at one time. Electrophoresis was continued until the blue tracker dye reached the end of the gel. The gels were stained with ethidium bromide solution and the DNA was visualised by ultra-violet illumination.

Restriction enzyme analysis. Plasmid DNA was cleaved with the restriction enzymes Hind III, EcoRI and Bam HI in conditions suggested by the manufacturers (New England Biolabs, CP Laboratories, Bishops Stortford, UK).

Plasmid elimination experiments were performed as described by O'Reilly et al. (1981). Strains were grown overnight in the presence of subinhibitory concentrations of ethidium bromide at $37^{\circ} \mathrm{C}$ or $43^{\circ} \mathrm{C}$. Normally a final ethidium bromide concentration of $100-150 \mu \mathrm{l} / \mathrm{ml}$ was suitable.

Transformation of S. aureus strain RN2677 (Novick et al., 1979) was performed by a modification of the protoplast method of Chang and Cohen (1979). A 50- $\mu$ l inoculum of an overnight culture of recipient strain RN2677 (rifampicin and novobiocin resistant) was added to $50 \mathrm{ml}$ of Penassay broth (Oxoid) and the culture was grown to an $\mathrm{OD}_{600}$ of 0.6 . Cells were 
harvested in detergent-free sterile-capped plastic centrifuge tubes in a bench centrifuge, washed in SMMP buffer (doubly-concentrated SMM, see below, in four-fold concentrated Penassay broth; Chang and Cohen, 1979), and resuspended in $2.5 \mathrm{ml}$ of SMMP; $100 \mu \mathrm{l}$ of lysostaphin $1 \mathrm{mg} / \mathrm{ml}$ in $0.5 \mathrm{M}$ sucrose, $0.02 \mathrm{M}$ maleate, $0.02 \mathrm{M} \mathrm{MgCl}_{2}, p \mathrm{H} 6.5$ (SMM buffer) was added and the tubes incubated at $37^{\circ} \mathrm{C}$ for $30 \mathrm{~min}$ to generate protoplasts. The protoplasts were transferred to a second sterile centrifuge tube, diluted with an equal volume of SMMP, harvested by centrifugation, and resuspended in $2.5 \mathrm{ml}$ of SMMP. The washed protoplasts were stable at room temperature for several hours.

For transformation experiments, $0.5 \mathrm{ml}$ of protoplast suspension was mixed with $0.5 \mu \mathrm{g}$ of plasmid DNA suspended in $100 \mu$ l of twice-concentrated SMM, then $1.5 \mathrm{ml}$ of $40 \%(\mathrm{w} / \mathrm{v})$ polyethylene glycol 6000 dissolved in twice-concentrated SMM was added with gentle mixing for $2 \mathrm{~min}$. Five $\mathrm{ml}$ of SMMP was added and the protoplasts harvested immediately by centrifugation at maximum speed in a bench centrifuge. The supernate was removed and the tube allowed to drain for a few minutes. The pelleted protoplasts were resuspended in $1 \mathrm{ml}$ of SMMP and left at $32^{\circ} \mathrm{C}$ for $4 \mathrm{~h}$ to allow expression of antibiotic resistance. Samples were then diluted and plated on to DM3 regeneration medium (Chang and Cohen, 1979) containing the selective antibiotic and rifampicin $(1 \mu \mathrm{g} / \mathrm{ml})$. Putative transformants appeared after 2 days and were purified on selective media, tested for resistance to rifampicin and novobiocin and screened for plasmid DNA. For this procedure to work reproducibly all media, glassware, pipettes and DNA samples had to be sterile and free of detergents that affect the stability of the protoplasts.

Assay of aminoglycoside inactivating enzymes. Assays were performed by the phosphocellulose binding technique of Benveniste and Davies (1973). Cells were harvested from 100-ml cultures grown overnight in Brain Heart Infusion broth (Difco) at $37^{\circ} \mathrm{C}$ and resuspended in $3 \mathrm{ml}$ of $32 \mathrm{~mm}$ Tris- $\mathrm{HCl}, 16 \mathrm{~mm} \mathrm{MgCl}, p \mathrm{H} \mathrm{7.6}$. The cells were treated with $200 \mu$ l of lysostaphin $1 \mathrm{mg} / \mathrm{ml}$ in $0.25 \mathrm{M}$ Tris- $\mathrm{HCl}, p \mathrm{H} 7.6$ for $10 \mathrm{~min}$ at $37^{\circ} \mathrm{C}$ then broken by ultra sonication (MSE, model 7100) using six 30-s bursts with cooling on ice. Cell debris was removed by centrifugation at $48000 \mathrm{~g}$ for $30 \mathrm{~min}$; the supernate was divided into $100-\mu \mathrm{l}$ volumes and stored at $4^{\circ} \mathrm{C}$ until required. Assays were performed for acetyl, adenyl and phosphotransferase activity.

Transduction was performed by the method of Asheshov (1966). Phages 80 and 85 from the International Typing Set were employed to transduce resistance determinants to RN2677 and SA1030 (Lacey and Lord, 1980).

Mixed culture experiments were performed as described by Lacey (1971) using a rifampicinresistant mutant of SA1030 as recipient.

\section{RESULTS}

\section{Screening of GMRSA for plasmids}

Several hundred clinical specimens of GMRSA have been collected since 1976 from infected patients in Dublin hospitals. Clinical studies described in an accompanying report (Cafferkey et al., 1983) have shown that the isolates belong to a limited number of phage groups. The GMRSA strains were often resistant to several other antibiotics including kanamycin and erythromycin. As a preparation for detailed genetic studies, c. 200 GMRSA strains isolated at different times during the study period from each hospital were screened for the presence of plasmid DNA. A uniform plasmid profile was detected even though individual strains often exhibited slightly different antibiotic resistance phenotypes (fig. 1). Isolates of phage types 77 and 85 were the first GMRSA strains to cause infections in the hospitals (table). All representative strains of these isolates that were screened harboured a plasmid of mol. wt $21 \times 10^{6}$ (fig. 1, tracks E and F). In all, 40 isolates that had been isolated during a 2-year period from four F.D.V.H. hospitals were examined; $40 \%$ of these isolates harboured an additional plasmid of mol. wt $3 \times 10^{6}$ (fig. 1, tracks $\mathrm{G}$ and $\mathrm{H}$ ) and were tetracycline resistant 
TABLE

Bacteriophage typing patterns and plasmid content of GMRSA isolates

\begin{tabular}{|c|c|c|c|}
\hline Phage type & $\begin{array}{l}\text { Date of } \\
\text { appearance } \\
\text { in hospitals }\end{array}$ & $\begin{array}{l}\text { Plasmids } \\
\text { detected } \\
\text { (mol.wt) }\end{array}$ & $\begin{array}{l}\text { Number of } \\
\text { isolates } \\
\text { screened }\end{array}$ \\
\hline $77 / 84$ & $\begin{array}{l}\text { F.D.V.H. } \\
1977-1978\end{array}$ & \multirow{4}{*}{$\begin{array}{c}21 \times 10^{61} \\
3 \times 10^{62} \\
21 \times 10^{6} \\
3 \times 10^{6} \\
24 \times 10^{62} \\
21 \times 10^{6} \\
24 \times 10^{6} \\
21 \times 10^{6}\end{array}$} & 21 \\
\hline 85 & $1977 / 1979$ & & 18 \\
\hline 90 at 100 RTD & $1978-1980$ & & 100 \\
\hline $6 / 47 / 54 / 84 / 85$ & 1979 & & 20 \\
\hline 90 at 100 RTD & $\begin{array}{l}\text { M.M.H. } \\
\text { 1979-1980 }\end{array}$ & \multirow{2}{*}{$\begin{array}{l}24 \times 10^{6} \\
21 \times 10^{6} \\
21 \times 10^{6} \\
1.7 \times 10^{6}\end{array}$} & \multirow[t]{2}{*}{12} \\
\hline $77 / 85$ & 1979 & & \\
\hline & & $1 \cdot 3 \times 10^{6}$ & 10 \\
\hline
\end{tabular}

$\mathrm{RTD}=$ routine test dilution.

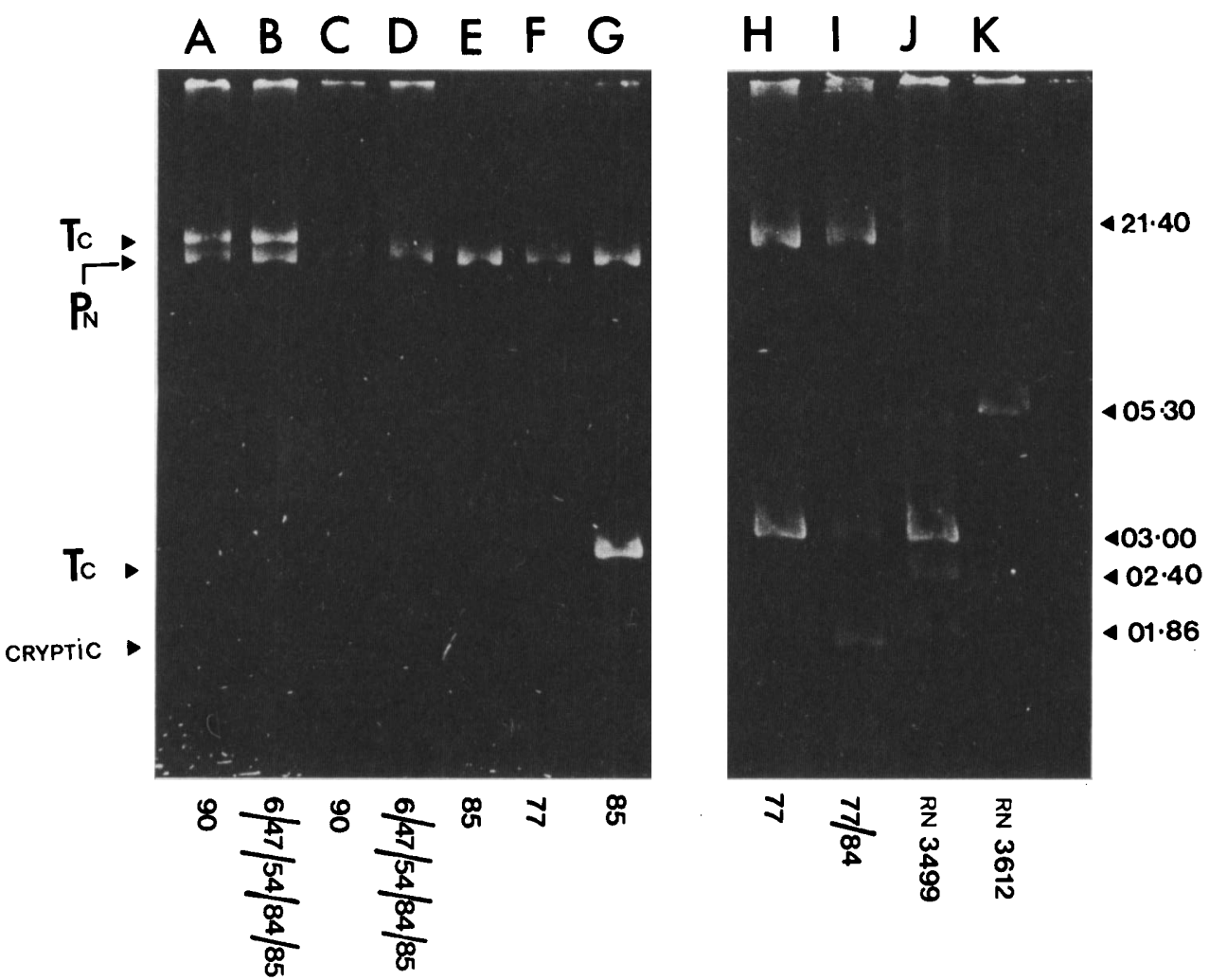

FIG. 1. Agarose gel electrophoresis of plasmid DNA isolated from GMRSA. The phage type of each isolate is indicated below tracks $\mathrm{A}-\mathrm{I}$. Tracks $\mathrm{J}$ and $\mathrm{K}$ contain plasmids of known mol. wt as controls (see Methods). Mol. wt $\left(\times 10^{\circ}\right)$ is shown on the right. $\mathrm{Tc}=$ tetracycline resistance plasmid; $\mathrm{Pn}=$ penicillinase plasmid. 
(Tc-R). None of the tetracycline sensitive (Tc-S) isolates harboured the $3 \times 10^{6} \mathrm{~mol}$. wt plasmid (fig. 1, tracks $E$ and F).

GMRSA strains that were untypable with standard phages but reacted with experimental phage 90 at 100 RTD appeared in the hospitals in 1977. These isolates quickly became the most common type of GMRSA isolated from infected patients. By early 1980 a small number of isolates of phage type 6/47/54/84/85 were isolated in one hospital. Plasmid screening again revealed a uniform plasmid profile for these strains and c. $40 \%$ of the isolates of both phage types were Tc-R. Such isolates harboured two plasmids of mol. wts $21 \times 10^{6}$ and $24 \times 10^{6}$ (fig. 1, tracks A and B). The remaining Tc-S isolates harboured only the $21 \times 10^{6}$ mol. wt plasmid (fig. 1, tracks $\mathrm{C}$ and D).

Sixteen GMRSA strains isolated in the M.M.H. group were screened. They were of phage type $77 / 84$ or type 90 at 100 RTD. The type $77 / 85$ isolates harboured plasmids of mol. wts $21 \times 10^{6}, 1.7 \times 10^{6}$ and $1.3 \times 10^{6}$ (fig. 1, track I). Isolates of type 90 exhibited the same plasmid profiles as the F.D.V.H. type 90 isolates.

A large number of gentamicin sensitive (Gm-S) strains of $S$. aureus isolated in the same hospitals have been screened for plasmid DNA. The isolates belonged to various phage types. Several plasmids that were never detected in GMRSA isolates were found in these strains. Furthermore, some of these isolates harboured plasmids of mol. wts $21 \times 10^{6}$ and $3 \times 10^{6}$ (results not shown). Thus although other plasmids were present in $S$. aureus within the hospitals, with the exception of the $21 \times 10^{6}$ and $3.0 \times 10^{6} \mathrm{~mol}$. wt plasmids, none of these were found in GMRSA isolates.

\section{Restriction enzyme cleavage of plasmid DNA from GMRSA}

Plasmid DNA purified from four isolates of each phage type was cleaved with the restriction enzyme $E c o$ RI (fig. 2). Analysis of the restriction fragments on agarose gels revealed that the $21 \times 10^{6} \mathrm{~mol}$. wt plasmids were closely related and probably identical in all strains. The $24.0 \times 10^{6} \mathrm{~mol}$. wt plasmid harboured by isolates of phage types 77 and 85 also gave rise to identical restriction fragments on digestion with EcoRI (fig. 2, tracks $C$ and D). The $3.0 \times 10^{6} \mathrm{~mol}$. wt plasmid was cleaved once with EcoRI in all cases. Cleavage of plasmid DNA with BamHI and HindIII also suggested that the plasmids of similar mol. wt were identical (not shown).

\section{Plasmid elimination experiments}

Selected isolates belonging to each of the phage types were grown under conditions that favoured the loss of plasmid DNA. Individual colonies were then screened for loss of antibiotic resistance determinants. Growth in the presence of sub-inhibitory concentrations of ethidium bromide or novobiocin at $43^{\circ} \mathrm{C}$ failed to eliminate most antibiotic resistance determinants at a detectable frequency. Tc- $R$ isolates of phage types 77 and 85 gave rise to Tc-S derivatives at a significant frequency. All Tc-S derivatives had lost the $3.0 \times 10^{6} \mathrm{~mol}$. wt plasmid. Tc-R isolates of type 90 or $5 / 47 / 54 / 84 / 85$ lost penicillin resistance (Pn-R) at frequencies of up to $10 \%$ after overnight growth. All Pn-S derivatives had lost the $21.0 \times 10^{6} \mathrm{~mol}$. wt plasmid. Interestingly, Tc-S isolates of phage types 90 and 5/47/54/84/85 did not lose Pn-R at a detectable frequency. 


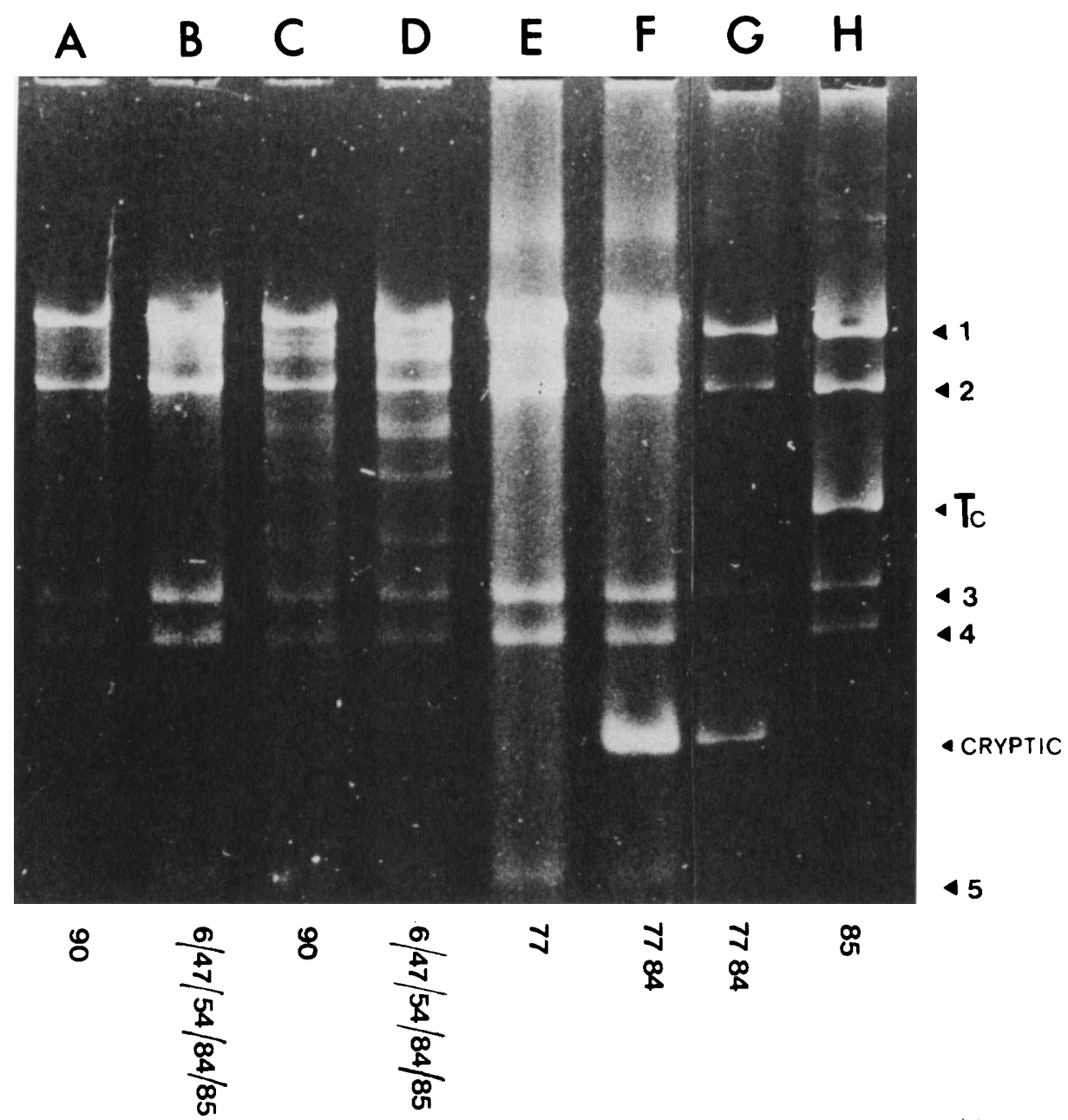

FIG. 2. Agarose gel electrophoresis of purified plasmid DNA cleaved with restriction enzyme EcoRI. The phage type of each isolate is indicated below each track. Tc indicates the $3.0 \times 10^{6} \mathrm{~mol}$. wt, Tc-R plasmid and "cryptic" refers to the $1.7 \times 10^{6} \mathrm{~mol}$. wt plasmid found in type $77 / 84$ isolates. Electrophoresis was on a $1 \%(w / v)$ agarose gel.

\section{Transfer of resistance determinants}

Recipient strain RN2677 was transformed with plasmid DNA from each of the phage types. Plasmid DNA isolated from Tc-R isolates of phage types 77 and 85 transformed RN2677 to Tc-R at high frequency ( 1 in $10^{5}$ ). All Tc-R transformants harboured the $3.0 \times 10^{6} \mathrm{~mol}$. wt plasmid (fig. 3, track D). Pn-R transformants occurred at a lower frequency $\left(1\right.$ in $\left.10^{7}\right)$ and all harboured the $21.0 \times 10^{6} \mathrm{~mol}$. wt plasmid (fig. 3, track C). Plasmid DNA prepared from isolates of phage types 90 or $5 / 47 / 54 / 84 / 85$ gave identical results for $P n-R$. From these types, Tc-R transformants were obtained at a similar frequency to $\mathrm{Pn}-\mathrm{R}$ and all Tc-R transformants harboured the $24.0 \times 10^{6} \mathrm{~mol}$. wt plasmid. RN2677 transformants resistant to gentamicin, amikacin, methicillin, kanamycin or erythromycin were not detected. 


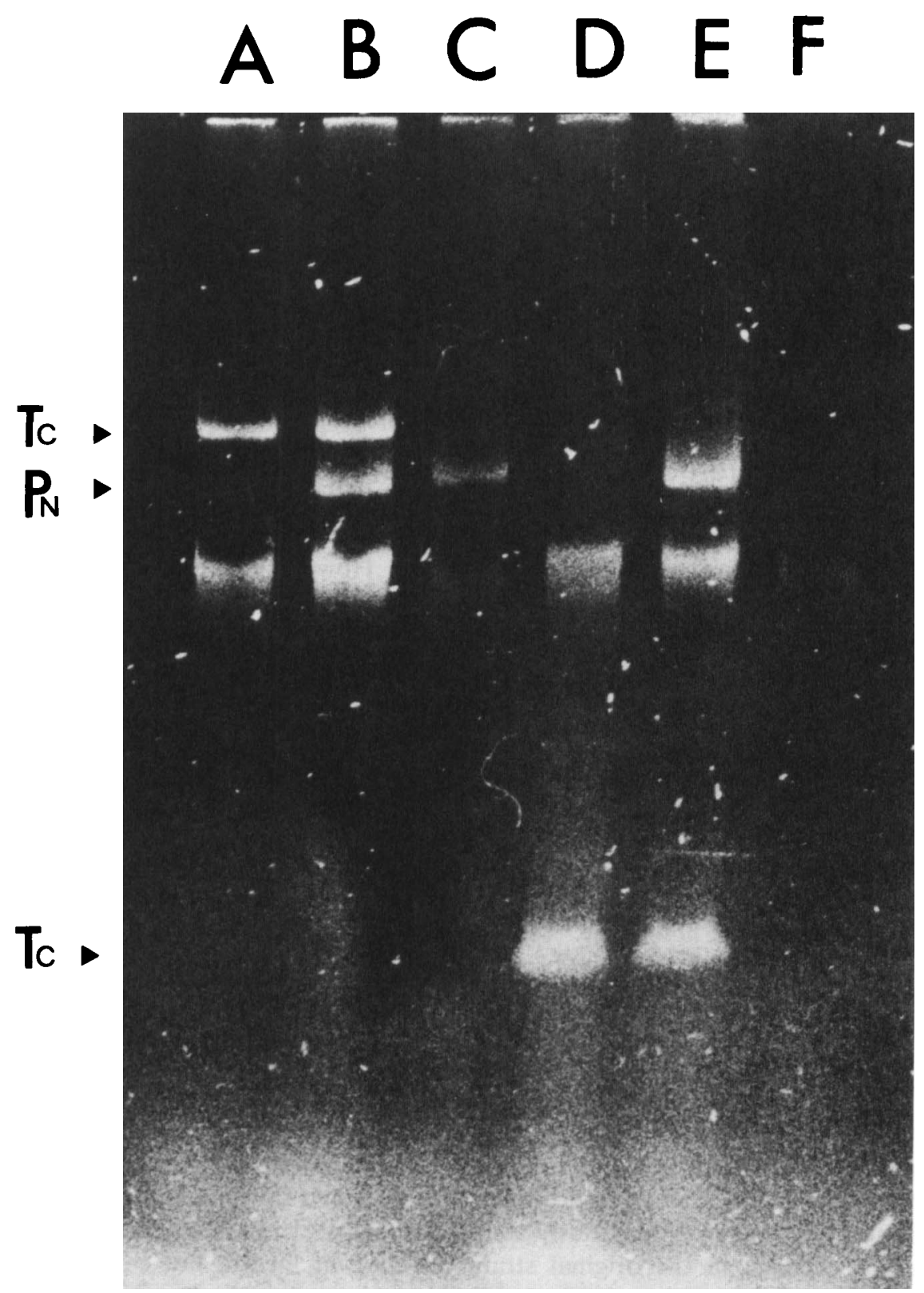

FIG. 3. Agarose gel electrophoresis of plasmid DNA isolated from RN2677 transformants. A, Tc-R transformant isolated after using type 90 DNA; B, type 90 DNA (control); C, Pn-R transformant isolated after using type 90 DNA; D, Tc-R transformant isolated after using type 85 DNA; E, type 85 DNA (control); F, Gm-R transductant of RN2677. Only chromosomal DNA can be seen in track F. Electrophoresis on different concentrations of agarose showed that no covalently closed circular plasmid DNA was obscured by this DNA. 
Tc- $R$ isolates of phage type 85 were used as donors in transduction experiments employing bacteriophage 85 from the phage typing collection. Neither Tc-R nor Gm-R was transferred to RN2677 or SA1030 (Lacey and Lord, 1980) in mixed culture experiments. Tc-R was readily transduced to these strains at frequencies up to $5 \times 10^{-5}$ and all transductants acquired the $3.0 \times 10^{6} \mathrm{~mol}$. wt plasmid. Gm-R was transduced to both recipients at a much lower frequency of $(1-5) \times 10^{-8}$. Plasmid screening of $\mathrm{Gm}-\mathrm{R}$ transductants failed to detect any new plasmid DNA. Gm-R could be transduced from SA1030 or RN2677 transductants by phage 80 at a similar frequency. No unselected antibiotic resistance was acquired by the transductants.

GMRSA and Gm-R transductants were assayed for aminoglycoside inactivating activity. Acetyltransferase and phosphotransferase activity was detected in all Gm-R strains of $S$. aureus but not in control strains.

\section{DISCUSSION}

This report is part of an epidemiological survey currently being carried out on nosocomial infections involving $S$. aureus in a group of nine Dublin hospitals. Gentamicin sensitive $S$. aureus strains isolated in these hospitals belong to a wide range of different phage groups (unpublished results). However GMRSA strains belonged to a limited number of phage groups and possessed a remarkably uniform plasmid profile and the evidence indicates that the GMRSA isolates may be related. A single plasmid of mol. wt $21.0 \times 10^{6}$ was responsible for resistance to penicillin in all the GMRSA isolates. This plasmid was also detected in gentamicin sensitive strains of $S$. aureus of several phage types isolated during the survey (G. Dowd, unpublished results). Chromosomally encoded penicillinase production was not detected in the GMRSA isolates although it does occur in other strains of $S$. aureus isolated in Dublin (O'Reilly et al., 1981). Two different plasmids of mol. wts $24.0 \times 10^{6}$ and $3.0 \times 10^{6}$ were responsible for tetracycline resistance (TC-R) although only $40 \%$ of the isolates carried this resistance. It is not known if the two Tc-R determinants are related or share DNA sequence homology. The $3.0 \times 10^{6} \mathrm{~mol}$. wt plasmid co-migrates in agarose gels with other well characterised small TC-R plasmids isolated in other countries.

Many of the antibiotic resistance determinants present in the isolates, including aminoglycoside, methicillin and erythromycin resistance, were not linked to detectable plasmids. Both methicillin and erythromycin resistance have been shown previously to be chromosomally encoded in some strains (Lacey, 1975). Several groups have shown that gentamicin resistance can be plasmid linked in $S$. aureus (de Saxe and Porthouse, 1979; Jaffe et al., 1980; Weinstein et al., 1982). Chromosomally encoded gentamicin resistance has been documented (Lacey and Lord, 1980) and may be more common than has been previously assumed. Gentamicin resistance may have been plasmid encoded in the original strains isolated in Dublin but could have been transferred subsequently to the chromosome as the number of isolates increased. The acquisition of a new antibiotic resistance determinant by $S$. aureus, especially one encoded on the chromosome, may involve a phage carrying the determinant. Transposition is likely to be involved in the integration of the resistance genes into the phage genome and the subsequent transfer of the determinant to the host chromosome. As yet we have no evidence that the GMRSA of different phage types are different strains or simply the same strain that has acquired or lost prophages. 
Another approach, possibly involving biotyping, is required to differentiate between the two possibilities. The existence of antibiotic resistance determinants on the $S$. aureus chromosome may lead to stabilisation of the determinant in the hospital environment in the absence of direct antibiotic selection. This would be especially true if the determinant was located in a strain that was efficient at colonising damaged epithilial surfaces.

Because $S$. aureus plasmids are non-conjugative, bacteriophages are believed to be principally responsible for the transfer of antibiotic resistance determinants. Thus both plasmid and chromosomally encoded determinants could be transferred at similar frequencies, especially if the resistance is transposable or encoded on a large plasmid that cannot be packaged intact into phage heads.

We thank Patrick McHale for help with some experiments, all colleagues who sent $S$. aureus isolates and Corinne Harrison for typing the manuscript. This work was supported by the Irish M.R.C.

\section{REFERENCES}

Asheshov, E. H. 1966. Chromosomal location of the genetic elements controlling pencillinase production in a strain of Staphylococcus aureus. Nature, 210, 804-806.

Benveniste, R. AND Davies, J. 1973. Mechanisms of antibiotic resistance in bacteria. Annual Review of Biochemistry, 42, 471-506.

Cafferkey, M. T., Hone, R., Falkiner, F. R., Keane, C. T. and Pomeroy, H. 1983. Gentamicin and methicillin resistant Staphylococcus aureus in Dublin hospitals: clinical and laboratory studies. Journal of Medical Microbiology, 16, 117-127.

ChANG, S. AND CoHEN, S. N. 1979. High frequency transformation of Bacillus subtilis protoplasts by plasmid DNA. Molecular and General Genetics, 168, 111-115.

De SAXe, M. AND Porthouse, A. 1979. Gentamicin resistance in Staphylococcus aureus. Lancet, 2, 370-371.

Hansen, J. B. AND Olsen, R. H. 1978. Inc P2 group of Pseudomonas, a class of uniquely large plasmids. Nature, 274, 715-717.

HoNE, R. and 7 others. 1981. Bacteraemia in Dublin hospitals due to gentamicin resistant Staphylococcus aureus. Journal of Hospital Infection, 2, 119-126.

Jaffe, H. W., Sweeney, H. M., Nathan, C., Weinstein, R. A., Kabins, S. A. and Cohen, S. 1980. Identity and interspecific transfer of gentamicin resistance plasmids in Staphylococcus aureus and Staphylococcus epidermidis. Journal of Infectious Diseases, 141, 738-747.

LACEY, R. W. 1971. High frequency transfer of neomycin resistance between naturally occurring strains of Staphylococcus aureus. Journal of Medical Microbiology, 4, 73-84.

LACEY, R. W. 1975. Antibiotic resistance plasmids of Staphylococcus aureus and their clinical importance. Bacteriological Reviews, 39, 1-32.

LACEY, R. W. AND LORD, V. L. 1980. Transfer of gentamicin resistance between cultures of Staphylococcus aureus in nutrient broth, serum and urine. Journal of Medical Microbiology, 13, 411-421.

Meyers, J. A., Sanchez, D., Elwell, L. P. and Falkow, S. 1976. Simple agarose gel electrophoretic method for the identification and characterisation of plasmid deoxyribonucleic acid. Journal of Bacteriology, 127, 1529-1537.

Novick, R. P., Edelman, I., Schwesinger, M. D., Gruss, A. D., Swanson, E. C. and Pattee, P. A. 1979. Genetic translocation in Staphylococcus aureus. Proceedings of the National Academy of Sciences, 76, 400-404.

O'Reilly, M., Dougan, G., Foster, T. J. and Arbuthnott, J. P. 1981. Plasmids in epidermolytic strains of Staphylococcus aureus. Journal of General Microbiology, 124, 99-107.

Price, E. H., Brain, A. ANd Dickson, J. A. 1980. An outbreak of infection with a gentamicin 
and methicillin resistant Staphylococcus aureus in a neonatal unit. Journal of Hospital Infection, 1, 221-228.

Shanson, D. C., Kensit, J. G. AND Duke, R. 1976. Outbreak of hospital infection with a strain of Staphylococcus aureus resistant to gentamicin and methicillin. Lancet, 2, 1347-1348.

Shanson, D. C. 1981. Antibiotic resistant Staphylococcus aureus. Journal of Hospital Infection, 2, 11-36.

Weinstein, R. A., Kabins, S. A., Nathan, C., Sweeney, H. M., Jaffe, H. W. and Cohen, S. 1982. Gentamicin-resistant Staphylococci as hospital flora: Epidemiology and resistance plasmids. Journal of Infectious Diseases, 145, 374-382.

Williams, R. E. O. AND RIPPON, J. E. 1952. Bacteriophage typing of Staphylococcus aureus. Journal of Hygiene (London), 50, 320-353. 